\title{
GLOBALISATION AND NATIONAL SECURITY ISSUES FOR THE STATE: IMPLICATIONS FOR NATIONAL ICT POLICIES
}

\author{
Jackie Phahlamohlaka ${ }^{1}$ \\ CSIR, South Africa
}

\begin{abstract}
The national security issues most impacted upon by globalisation are generally found to fall into three categories: the nature of security threats in a globalised world, the effects of the phenomenon of globalisation on the pursuit of national security, and the erosion of the exclusivity of the state as a provider of national security. In this chapter I examine the security risks associated with ICT, and in particular the Internet which is not constrained by territorial boundaries traditionally defining states and their sovereignty. Also, I point out the need for developing and implementing agile security related ICT policies to remain on the national security research agenda of all states.
\end{abstract}

Keywords: Globalisation, national security, information and communications technologies, national ICT policies, security threats

\section{Introduction}

There is a general agreement in the literature that systematic studies analysing the link between globalisation and national security are necessary, but lacking. Cha [4] for instance points out that in spite of the plethora of literature on security and globalisation, there is relatively little work written by security specialists that interconnects the two. Because both globalisation and national security are multidimensional constructs whose bringing into operation is mainly enabled by Information and Communication Technologies (ICT), the lack of a systematic study of their interconnections presents a challenge for security related national ICT policies. So challenging are these constructs that most states are taking their time in publicly pronouncing their national security policies, let alone their ICT related national security policies. In an earlier study upon which this chapter draws, completed as part of the Executive National Security Programme (ENSP) by the author [10] in June 2007, a research approach was proposed that could be used by other interested researchers in further systematic studies linking globalisation and national security.

\footnotetext{
${ }^{1}$ Permission to use the results of the analysis from the Commadant Research Paper (CRP) of ENSP 15/07 was granted by the South African National Defence College.
}

Please use the following format when citing this chapter:

Phahlamohlaka, J., 2008, in IFIP International Federation for Information Processing, Volume 282; Social Dimensions of Information and Communication Technology Policy; Chrisanthi Avgerou, Matthew L. Smith, Peter van den Besselaar; (Boston: Springer), pp. 95-107. 
Realising that most of the analyses attempting to draw a link between globalisation and national security were not based on or did not use any well researched theoretical perspective, we developed a framework in the ENSP study that combined the Ripsman and Paul [11] analysis framework and the processbased research framework proposed by Roode [5], to guide our analysis. A brief description of the framework is presented in section 3. Following this framework and the approach just mentioned, the author found that the national security issues most impacted upon by globalisation, generally fall into three categories: (1) the nature of security threats in a globalised world, (2) the effects of the phenomenon of globalisation on the pursuit of national security, and (3) the erosion of the exclusivity of the state as a provider of national security.

The proposed research approach is important because most of the literature attempting to link globalisation and national security was found to be very shallow and unhelpful from a research point of view. In line with this observation, Siponen [13] conducted a literature review on Information Systems (IS) security research between 1990 and 2004 and found that IS security research is chronically underdeveloped in terms of theory.

In this chapter, the results of the ENSP paper analysis are used to argue and demonstrate that globalisation renders the development and the implementation of ICT policies that are compliant to traditional national security requirements difficult across all states. The argument and the demonstration are structured in line with the identified national security issues most impacted by globalisation presented in the preceding paragraph.

The rest of the chapter is organised as follows. In the next section, the key concepts used in the chapter, namely globalisation, national security and the state are explored. This is followed by a discussion of the key national security issues for the state most impacted upon by globalisation after which a detailed argument on what the author considers the implications of these issues to be for security related national ICT policies is presented. The chapter ends with a concluding discussion.

\section{The key concepts explored}

Taken separately, the literature on globalisation and national security is not scarce. As well, their definitions, perspectives and descriptions are vast and varied. As pointed out in the introduction, however, it is systematic studies analysing the link between globalisation and national security that are necessary, but lacking. The brief exploration of these concepts as presented below represent only a tiny fraction of what has been written in scholarly journals, books and conference proceedings, let alone the volumes of text available on the Internet. 


\section{$2.1 \quad$ Globalisation}

Globalisation is described and defined in many different ways. Frost [7] quotes several sources, each differently describing globalisation. Amongst others, he quotes Friedman's description of globalisation as a "dynamic, ongoing process involving the inexorable integration of markets, non-states, and technologies to a degree never witnessed before." Frost also quotes the National Security Strategy issued by the White House in December 1999 which defined globalisation as "the process of accelerating economic, technological, cultural and political integration." The literature is loaded with many other descriptions and definitions, although most are very shallow.

Frost then arrived at his own description of globalisation as "a process leading to greater interdependence and mutual awareness (reflexivity) among economic, political and social units in the world, and among actors in general. It is an ideology with multiple meanings and lineages, sometimes appearing to be loosely associated with neo-liberalism and with technocratic solutions to economic development and reform, but also linked to cross-border advocacy networks and organisations defending human rights, the environment, women's rights or world peace" [8].

Guillen [8] writes in conclusion that definitions and timing aside, one of the persistent problems afflicting the study of globalisation is that it is far from a uniform and inexorable trend. Rather, globalisation is a fragmented, incomplete, discontinuous, contingent, and in many ways contradictory and puzzling process. Its study attracted and continues to attract great interest, with an explosion in the number of articles and books on globalisation published in the economic, sociological, and political literatures. He then identifies and discusses what he calls the five key debates: 1. Is it really happening? 2. Does it produce convergence? 3. Does it undermine the authority of nation-states? 4. Is globality different from modernity? 5. Is a global culture in the making? He goes into details in addressing each of these questions and an interested reader can consult the cited reference.

From the exploration of this concept as presented, and in relation to national security, this author concludes that globalisation is about the creation, protection, and sustenance of national interests in the process of global interaction.

\subsection{National security}

National Security as a concept is associated with the history of the United States of America following the Second World War, with the US Congress passing the first National Security Constitution in 1947. It traditionally had to do with the protection of the state against external aggression through economic, military, political, and diplomatic means. Recently however, it has been broadened to include human security - a people-centred approach to security, linking development to security and broadening both the identification of possible threats and the actors responsible for producing and resolving insecurity. 
The literature indicates that there are as many definitions of National Security as there are students. One definition that caught the author's eye is the one given by David Jablonsky [9], who defines national security as that part of government policy whose objective is to create national and international political conditions that are favourable to the protection or the extension of vital national values against existing or potential adversaries.

According to Jablonsky, national security is defined in terms of the respective elements of the power base of a state, and is allotted differing priorities within different states, depending on the declared vital and national interests of such a state. All definitions of national security include the concept of national power, without which it is argued, there can be no security. The elements of national power fall into either of the two categories of determinants of power. The natural determinants and the social determinants. The natural determinants (geography, resources, and population) are concerned with the number of people in a nation and with their physical environment. Social determinants (economic, political, military, psychological, and informational) on the other hand concern the ways in which the people of a nation organize themselves and the manner in which they alter their environment [9]. From the literature, one can define national security as: The provision of security to the state and of human security to its citizens as well as the protection of national and human interests together with state borders through the projection of national power.

To understand national security, one must understand the elements of national power and how they interrelate. It is convenient to organize the study of national power by distinguishing between natural and social determinants of power. For instance, resources are a natural factor, but the degree to which they are used is determined socially. Population factors, in particular, cut across the dividing line between both categories. The number of people of working age in the population affects the degree of industrialization of a nation, but the process of industrialization, in turn, can greatly alter the composition of the population.

Jablonsky points out that where people live will influence what they possess, that the number of people will influence how much they possess, what their historical experience has been will affect how they look at life, how they look at life will influence how they organize and govern themselves, and all these elements weighed in relation to the problem of national security will influence the nature, size, and effectiveness of the armed forces.

It is further argued that as a consequence, not only must each separate element be analyzed, but the effects of those elements on one another must be considered, indicating that these complexities are compounded because national power is both dynamic and relative. There is a formula to develop a rough estimate of "perceived" national power - focused primarily on a state's capacity to wage war: 
$\mathrm{Pp}=(\mathrm{C}+\mathrm{E}+\mathrm{M}) \mathrm{x}(\mathrm{S}+\mathrm{W})$ in which:

$\mathrm{Pp}=$ Perceived power

$\mathrm{C}=$ Critical mass: population and territory

$\mathrm{E}=$ Economic capability

$\mathrm{M}=$ Military capability

$\mathrm{S}=$ Strategic purpose

$\mathrm{W}=$ Will to pursue national strategy

One of the lessons from this formula is that the more tangible elements $(\mathrm{C}, \mathrm{E}$, $\mathrm{M})$ that can be quantified objectively also involve varying degrees of subjective qualifications. The formula demonstrates that national power is a product-not a sum of its components. It thus serves as a reminder of the importance of relational and contextual aspects. In demonstrating the usefulness of this formula, reference is made to how the United States discovered in Vietnam that no matter how large the sum of the more tangible economic and military capabilities in relation to an adversary, their utility is determined by the intangibles of strategic purpose (S) and national will (W).

\subsection{The state}

The State as a concept used in this chapter refers to the modern state, historically linked to the Peace of Westphalia that in 1648 ended the thirty years' religious war in Europe. Several historians tell us that it was during the Peace of Westphalia that stipulations were made to the effect that the citizens of nations needed to be subjected to the laws of their own governments [14]. States or governments can be classified according to how much autonomy they allow their subsystems such as churches, unions, colleges, and other organs of civil society freedom to run their own affairs

Totalitarian states permit little or no subsystem autonomy. They have an official and dogmatic ideologies to which all social institutions must adhere. Democratic states give a high degree of independence to subsystems. There are some limits for the conduct of any private association, but in general, a democratic state will allow as much autonomy as is consistent with the general well-being of the society [14]. Labour unions for example can strike without fear of state reprisal, except when the nation's security is affected. No subsystem has absolute freedom, but most are allowed to run their own affairs unless they threaten the public interest.

States differ not only in the degree of initiative they allow all subsystems but also in the way political power is distributed among its different levels. Nations can be classified as unitary states or federal states, depending on the way they distribute government authority. For example Great Britain, France, Italy, Israel, and most other nations are unitary states. A single national government exercises supreme power and can override the decisions of local governments. Such actions are unlikely in federal states such as the United States, Germany, Australia, and 
Canada where power is divided between the national government and provincial governments.

This brings us to the end of the exploration of the key concepts used in this chapter. We now return to the national security issues most impacted upon by globalisation in order to lay a foundation for our argument regarding the implications and the associated challenges related to the development and implementation of national ICT policies.

\section{The national security issues most impacted upon by globalisation}

Ripsman and Paul [11] performed an impressive literature review on globalisation and national security out of which they distilled three batches/sets of propositions regarding military doctrines and defence policies, for a total of nine propositions. A summary of the batches and their corresponding propositions is presented below. The first batch concerned the nature of security threats in a globalised world, the second concerned the effects of the phenomenon of globalisation on the pursuit of national security, and the last related to the erosion of the exclusivity of the state as a provider of national security.

Their framework of analysis entails investigating the validity of these propositions by examining the military doctrines and defence policies of four categories of states which they describe as the Major Powers and Global Social Forces, the States in Cooperative Regional Subsystems, the States in Competitive Regional Subsystems, and the Weak and Failed States as well as by studying empirical data on national military establishments since the late 1980s.

The three batches with the nine propositions about these categories of states are briefly described next.

BATCH A. The nature of security threats in a globalised world:

Proposition 1: A shift in the nature of wars from Clausewitzian interstate wars to "wars of a third kind." Civil ethnic wars and wars between small states have taken the place Clausewitzian interstate wars.

Proposition 2: States, particularly the United States, face the challenge of "post-industrial warfare." This concept refers to a new kind of threat: global assault by unprofessional, ideological combatants, operating in deprived areas, targeting civilians and businesses.

Proposition 3: National security increasingly includes the non-defence areas of trade, ecology, and health as threats are increasingly economic, environmental, and disease-related.

BATCH B. The effects of the phenomenon of globalisation on the pursuit of national security:

Proposition 4: National conscription and the size of the military apparatus are declining. 
Proposition 5: Defence spending is declining.

Proposition 6: National military doctrines are abandoning offence in favour of defence or deterrence.

Proposition 7: Military establishments are shifting from being war fighters to police forces.

BATCH C. Erosion of the exclusivity of the state as a provider of national security:

Proposition 8: States are privatizing security by including non-state actors in defence activities.

Proposition 9: States are increasingly pursuing security through regional institutions.

By combining the Ripsman and Paul's analysis framework, with all the above propositions and the process-based research framework developed by Roode [4] in the ENSP study, the author was able to generate a set of questions enabling a deeper probing into these national security issues most impacted upon by globalisation. Roode's process-based approach is based on the taxonomic framework of Burrell and Morgan [3].

The purpose of the taxonomic framework of Burrell \& Morgan is to create a set of perspectives on the problem space, in which one consciously traverses the problem space (with its underlying ontological and epistemological assumptions) in order to develop a richer understanding of the nature of the concept under investigation. But unlike Burrell and Morgans' framework, Roode's approach allows the researcher to deliberately pose different questions to explore different aspects of the problem or situation at hand. According to Roode, the researcher is not required to accept the assumptions associated with one question, but merely enquires about different facets of the research problem to obtain as much information about it as possible. One may choose to focus only on one type of question, for instance the "How does" type question(s) in a particular study. The framework for the approach is shown in Figure 1.

(What is?) With this question the fundamental nature or essence of the research problem is first explored. The question aims at exposing the structure of the problem or the meaning of the underlying concepts or ideas. The purpose is to enquire radically and critically about the problem domain and its accompanying paradigm(s) in order to be able to describe the problem precisely and unambiguously. The fundamental assumption here is that such universally accepted descriptions for the concepts, ideas, and problems do exist.

(Why is?) The purpose of this question is to explain the real-life behaviour or characteristics of the phenomenon or problem. In doing so, the focus is on determining relationships between aspects of and/or variables within the problem domain. There is a fundamental assumption underlying this question, namely that these relationships, when uncovered, can be used to generalise about the problem domain and causal consequences. 
(How does?) In answering this question the phenomenon or problem is directly observed and described as it manifests itself in reality.

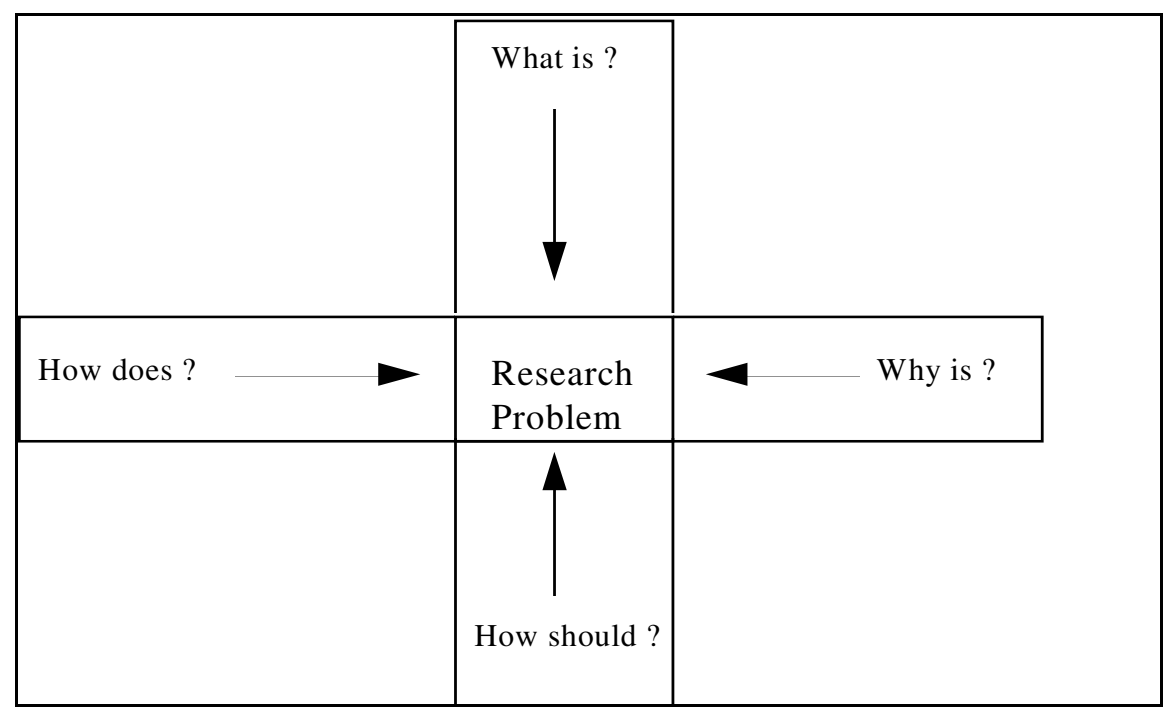

Figure 1: Research questions space (Roode, 1993, p. 11)

(How should?) This question focuses on the conclusions, implications or normative aspects of the research results. It is an evaluation of the results or new insights obtained during the research. In some cases it might lead to prescriptive conclusions regarding the problem domain - in other cases it might enhance the understanding of the problem domain or redefine it.

The two research questions that the ENSP study sought to address were:

What are the national security issues of the state most impacted upon by globalisation?

What institutional means could be put in place in order to effectively deal with this impact to enhance the security of the state?

For the design of the study, these research questions were mapped onto the Ripsman and Paul's research approach, not according to separate categories of states as described by Ripsman and Paul, but several sub-questions were raised instead, in accordance with the process-based research framework for each batch of propositions. In other words, synchronizing the Ripsman and Paul's framework for analysis and the process-based research framework gave us two major benefits. First, it gave us a framework for raising the research questions and aligning them 
with a sound theoretical process as well as a basis, in the form of propositional batches, on which further questions, using the process-based research framework, could be raised for a deeper analysis. For instance, the sub-questions corresponding to each of the propositional batches raised in the next section were found to be appropriate.

It is in discussing the said further probing questions in the next section that implications for security related national ICT policies we examine in this chapter will become apparent.

\section{Implications of these issues for security related national ICT Policies}

BATCH A. The nature of security threats in a globalised world:

What is the current nature of security threats in a globalised world?

Cyber warfare poses a large threat to highly computerised societies. For instance, within the context of globalisation, which state can claim a good capability to understand the full scale of its vulnerability within its information infrastructure and all its networks? Could a national ICT policy be developed that could be founded on the principle of protecting and exploiting the use of cyberspace? The latest information warfare literature reports increasing methods for conducting distributed attacks and identity theft on the internet, called botnets [1]. Botnet attacks include email spamming, distributed denial of service, port scanning, remote exploitation of vulnerabilities, and self propagation to expand the botnet's size. Combined with the asymmetrical nature of information warfare and the possible inapplicability of national and international laws, it is difficult for a state to declare ICT application dominance in the projection of its national power. Unlike traditional weapon technologies, access to ICT no longer requires substantial financial resources or state support. Terrorists, drug cartels, organised crime, spies, and hackers can, with relative ease, access and offensively use ICT to support their causes and thus easily pose as threats to national security of any state.

National borders are becoming irrelevant in the global and information environment and globalisation and ICT remove the differentiation between international and domestic threats. The rapidly changing nature of the threats enabled by globalised ICT infrastructure makes vulnerabilities difficult to understand and to identify.

There is no front-line to ICT enabled information warfare. Potential battlefields are anywhere networked systems allow access.

How then do states develop sufficiently agile ICT policies to deal with this current nature of security threats in a globalised world? 
BATCH B. The effects of the phenomenon of globalisation on the pursuit of national security:

How does globalisation positively contribute to national security of the state?

Globalisation facilitates interaction among groups that define themselves in terms of values, for instance human rights groups and women advocacy groups, across national boundaries. It changes and accelerates the pace with which people interact, communicate, and do business.

Computer networks and the Internet, for instance, democratise access to information and knowledge. Computer networks enable states to differently exercise their national power, especially through their effective use of information and communications technologies. States across the globe are able to rapidly move goods, information, and services.

The global economy increasingly relies on complex, interconnected network control systems for communications, energy distribution management, air, land and sea traffic management, and financial transactions. National assets can no longer be protected by traditional military and/or mechanical security means only. Because these global effects have no boundaries, they must be addressed both locally and internationally.

\section{How does globalisation negatively contribute to national security of} the state?

In a globalised world, all states face competition amongst themselves and other forms of non-state organisation. Technological globalisation makes it possible, through television and access to the Internet, for the disadvantaged and impoverished people around the globe to see how things are in other parts of the world in relation to their own, resulting in pressure being put on their own states for the improvement of their livelihood. States have limited avenues to influence the agenda of multinational businesses and agencies as well as less capacity to control information flow, goods, and services across its borders. International organised crime uses the computer network infrastructure to undermine state efforts in curbing their illegal activities. Highly networked and computerised nations are more vulnerable to cyber warfare. There are winners and losers in the global world as its effects are uneven. The question then becomes who must lose and to what extent? Or as Dexter [6] puts it, the nuances of who wins and loses what, when, and how are equally important.

Schwab paints a very gloomy but real picture on this question from a developing country's point of view:

"The nations of the developing world are essentially non-participant observers, watching helplessly as their commodity prises rise or fall, bond rates tumble or soar, interest on borrowed capital fluctuates, while currencies flood or evacuate the market place. Their domestic 
businesses can be made or broken in a split second, even as prices received for their agricultural or mineral products and the very amounts they can sell abroad are calculated in London, Paris, New York, Chicago, or Milan" [12].

For instance, the only sources of national security economically in the small country of Granada, the bananas, have to be opened for trade liberalization. If the sellers in Granada cannot determine the selling price of the only commodity that they have due to liberalised markets, what would this mean for the continued existence of that state?

BATCH C. Erosion of the exclusivity of the state as a provider of national security:

What are the visible signs that the exclusivity of the state as a provider of national security is being eroded?

Frost's [7] argument is compelling on this question. He argues that the combination of technology, international institutions, local governments, and nonstate actors is diluting the states' monopoly on governance and creating new forms of power. He says that although states remain sovereign, their leaders are choosing to shift some of their power to international institutions because of the need for new rules to govern global transactions and to respond to new global threats. In effect, states are choosing to share their power with multinational business, international organisations, and sub-state social groups.

States are directly and indirectly compelled to comply with the international economic system due to economic globalisation. It is difficult to distinguish in cyberspace among the actions of terrorist, criminals, and nation states and thus difficult for states and their institutions to protect themselves against cyber attacks. Consequently, developing ICT policies to effectively deal with these on a state by state basis is a challenging task.

\section{Concluding discussion}

Following a structured approach and the results of an earlier study that the author undertook, we have demonstrated in this chapter that globalisation renders the development and the implementation of ICT policies that are compliant to traditional national security requirements difficult across all states.

There are several implications for security related national ICT policies following the current nature of security threats pointed above. Key amongst them are Internet governance and e-government policies.

Most developed, as well as some of the developing states, have e-government systems in which satellite and other forms of wireless communication systems are used. While enhancing communication and effectiveness, they also increase the vulnerability of these states to information warfare. These kinds of threats require 
that policies that are based on anticipapted scenarios be considered during the development of communication systems to guarantee sufficient protection. As Baskerville [2] points out, agile information security development that anticipates threats and rapidly deploys necessary safeguards in the context of shifting systems landscapes amid pervasive systems threats needs to be developed. Advanced firewalls and virtual private networking can be used to fragment the organisational information system into security compartments and to extend a secure network architecture across unsecured public networks such as the Internet. I fully agree with Baskerville that while these are useful tools, research into techniques for applying these tools in dynamic environments is lacking. Approaches and methodologies in support of emergent security, necessitated by rapidly changing nature of threats enabled by ICT and the Internet, are urgently needed.

The underlying concern with both globalisation and national security is that of the safeguarding of interests, both human and national interests. Because ultimately national security is about the security of the individual citizen, the protection of the individual's interests by the state is as important as the protection of the interest of the state. In a globalised world, the capability with which states successfully navigate these webs of interests will determine the extent to which they are advantaged or disadvantaged by globalisation.

With the Internet not being constrained by territorial boundaries traditionally defining states and their sovereignty, the goal of developing agile security related ICT policies and their implementation must remain on the national security research agenda of all states. Even if it were possible to develop the various ICT policies to address the specific vulnerability areas mentioned earlier on in this section, integrating them into national security assurance would remain a challenge, but an important research area for all states.

\section{References}

[1] Ahn, G., Paxton, N, \& Pearson K. (2008). Understanding IRC bot behaviors in network-centric attack detection and prevention framework, Proceedings of the $3^{\text {rd }}$ International Conference on Information Warfare and Security. University of Nebraska, Omaha, USA, 24-25 April 2008.

[2] Baskerville, R. (2004). Agile security for information warfare: A call for research. Proceedings of the European Conference in Information Systems.

[3] Burrel,G. and G. Morgan,G. (1979). Sociological pradigms and organizational analysis, London: Heinemann.

[4] Cha, V.D. (2000). Globalisation and the study of international security. Journal of Peace Research, 37(3), 391-403.

[5] Dewald Roode, D. (1993). Implications for teaching of a process-based research framework for Information Systems. In Smith, L. (Ed.). Proceedings of the International Academy for Information Management Conference, Orlando, Florida.

[6] Dexter, P. (2006). Globalisation: solidarity forever, Financial Mail, 07 May 2004, available on http://www.fm.co.za/cgi-bin/pp-print.pl. Accesses 26 June 2006. 
[7] Frost, E.L. (2002). Globalisation and national security: A strategic agenda, in R.L Kruger, and E.L. Frost, (Eds.) The global century, globalisation and national security, Hawaii: University Press of the Pacific.

[8] Guillén, M.F. (2000). Is globalisation civilizing, destructive or feeble? A critique of five key debates in the social-science literature. Annual Review of Sociology, 27 (June 2000 Version).

[9] Jablonsky, D. (2001). National power. In Cerami, J.R., Holcomb, J.F, Jr. (eds). U.S. Army war college guide to strategy.

[10] Phahlamohlaka, L.J. (2007). Globalisation and national security issues for the state. CRP, South African National Defence College, South Africa, June 2007.

[11] Ripsman, N.M and Paul, T.V. (2005). Globalisation and the national security state: A framework for analysis. International Studies Review 7, 199-227.

[12] Schwab, P. (2001). Globalisation and Africa, in Africa: A continent self-destructs. New York: Palgrave.

[13] Siponen, M. (2005). A critical assessment of IS security research between 1990-2004. Proceedings of the European Conference in Information Systems.

[14] Trager, F.N. \& Simonie, F.L. (1989). An introduction to the study of national security, in Frank, N. Trager and Philip, S. Kronenberg (eds.), National Security and American Society, Theory, Process, and Policy, Manhattan: University press of Kansas. 